\title{
Synovial Metaplasia- A Case Report of Synovial Chondromatosis in a Young Adult
}

\author{
Kannedari Rindu Sahithi' ${ }^{1}$, Zaheda Kausar ${ }^{2}$, Anunayi J. ${ }^{3}$
}

${ }^{1}$ Department of Pathology, Osmania Medical College, Koti, Hyderabad, Telangana, India. ${ }^{2}$ Department of Pathology, Osmania Medical College, Koti, Hyderabad, Telangana, India.

${ }^{3}$ Department of Pathology, Osmania Medical College, Koti, Hyderabad, Telangana, India.

\section{INTRODUCTION}

Synovial chondromatosis is an uncommon benign condition emerging from the synovial membrane of the joints, synovial sheaths or bursae around the joints ${ }^{1}$. Synovial chondromatosis commonly influences the big joints in the third to fifth decade of life. The motivation behind this case report is to record this uncommon synovial pathology in 25 years young male which required open synovectomy and debridement to treat it. Synovial chondromatosis is an uncommon benign condition. Patients generally present with swelling, pain and including the synovial covering of joints, synovial sheaths and movement restriction ${ }^{2}$. It is the metaplastic procedure of synovium. It affects mainly large joints; knee, hip, which is an uncommon age group for this synovial pathology and shoulder, lower leg and wrist. Inclusion of smaller joints additionally, which incorporates distal radioulnar, peripheral synovium, which supposedly has tibio-fibular, metacarpophalangeal and metatarsophalangeal not been archived in before reports ${ }^{2}$. Bursae around the joints are additionally significant uncommon areas for synovial chondromatosis ${ }^{3}$. It typically shows in third to fifth decade of life. It is a rare case in 25 years young male presented with swelling and pain over right knee since 3 years.

\section{PRESENTATION OF CASE}

A 25 years old male presented with complaints of pain in right knee since three years and swelling since two years, occasionally associated with fever. Effusion is seen just above the knee and increased on exertion, patient had difficulty in walking, sitting cross legged and squatting. Patient had antalgic gait. There was no deformity. Anteriorly, effusion noted in the suprapatellar extending medially and laterally, diffuse effusion present, mild quadriceps wasting seen. Laterally, mild effusion present.
Corresponding Author: Dr. Zaheda Kausar, Flat No 203. York Enclave, 6/66/6, Khizra Colony, Hyderabad-500089, Telangana, India.

E-mail: zahedar11@gmail.com

DOI: $10.14260 /$ jemds/2020/69

Financial or Other Competing Interests. None.

How to Cite This Article: Sahithi KR, Kausar Z, Anunayi J. Synovial metaplasia- a case report of synovial chondromatosis in a young adult. J. Evolution Med. Dent. Sci. 2020;9(05):306308, DOI: $10.14260 /$ jemds/2020/69

Submission 29-08-2019,

Peer Review 26-12-2019,

Acceptance 02-01-2020,

Published 03-02-2020. 
X-ray, right knee aspirate- $90 \mathrm{ml}$ of serous fluid is aspirated and sent for cytology and microbiology. Knee aspiration cytology showed scattered neutrophils in proteinaceous background. Microbiology culture showed no organisms found and Gram stain smear shows no pus cells and no organism, acid fast staining did not show acid fast bacilli.
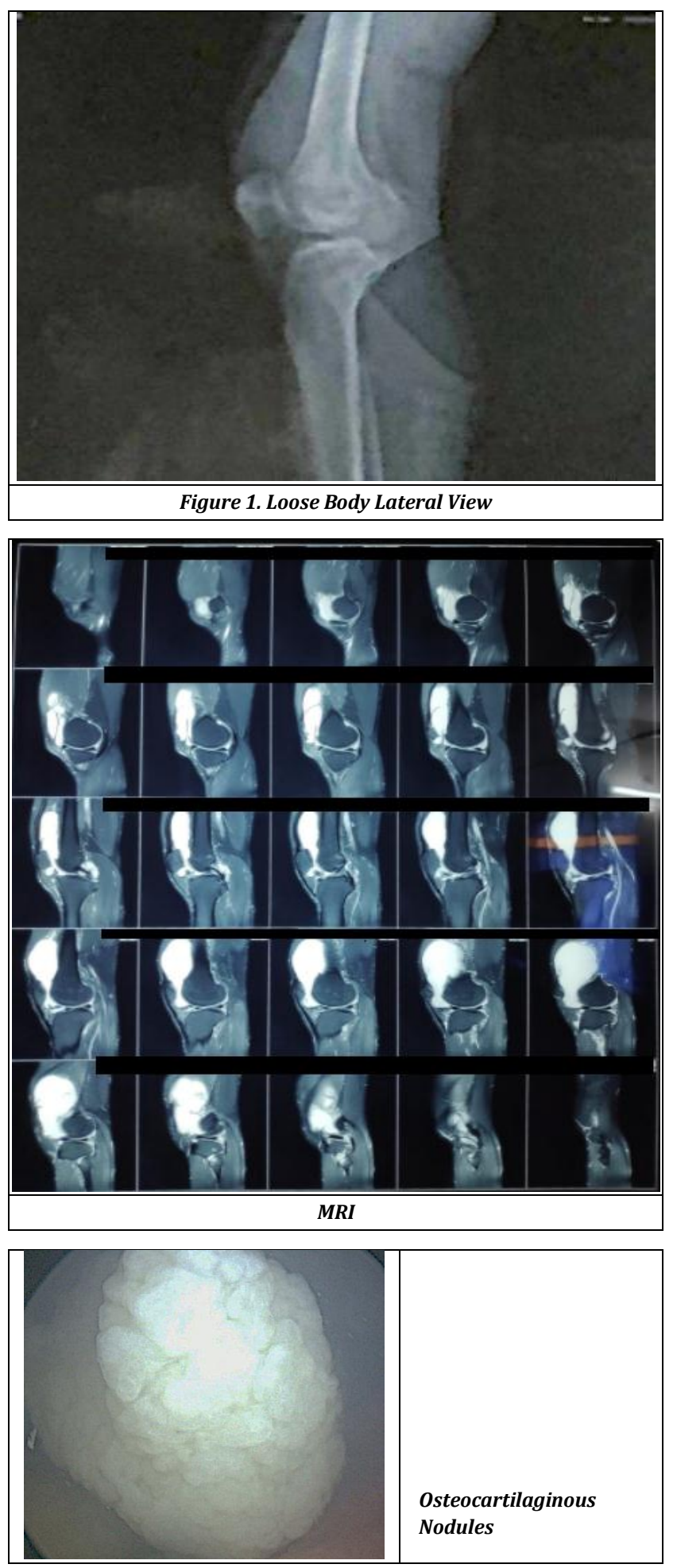

\section{CLINICAL DIAGNOSIS}

\section{DIFFERENTIAL DIAGNOSIS}

Villonodular Synovitis

Chronic Tubercular Synovitis Right Knee

\section{PATHOLOGICAL DISCUSSION}

Patient underwent arthroscopic synovial biopsy right knee and synovectomy. Specimen sent for histopathology.

\section{Histopathology}

Received pearly white cartilage bits with fibrofatty tissue.

\section{Gross}

Numerous round osteocartilaginous nodules.

\section{Histopathology Report}

Multiple sections studied from right knee synovial biopsy shows synovial tissue and multiple nodules of chondroid tissue and few muscle bundles.

\section{Impression}

Synovial chondromatosis (metaplasia) right knee biopsy.


Chronic Synovitis 


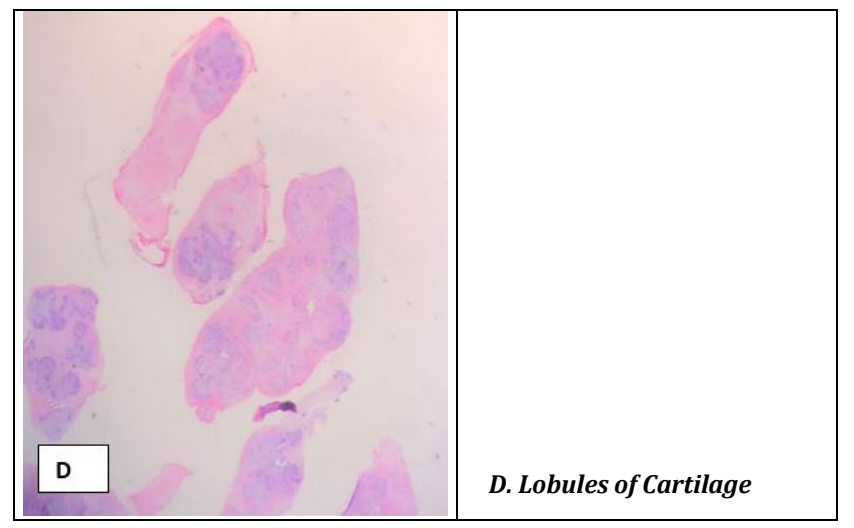

\section{FINAL DIAGNOSIS}

Synovial Chondromatosis Right Knee

\section{DISCUSSION}

Synovial chondromatosis is an uncommon metaplastic condition which is characterized by arrangement of cartilaginous bodies inside the synovium and sub synovial connective of the larger joints ${ }^{4}$. There are three stages in the recurrence. Stage 1-Active intra synovial disease without loose bodies. Stage 2-Active intrasynovial disease with the arrangement of loose bodies. Stage 3-Loose bodies in general calcify and synovitis becomes inactive without synovial abnormality 5 . Presents in their third to fifth decade, however there are reports of Peculiarities for this situation is its presenting age and its event in young adult. Synovial chondromatosis is more common in males ${ }^{6}$. Mostly unilateral, yet bilateral involvement has been seen. Plain radiograph, ultrasound, CT and MRI are the imaging modalities which can be utilized to help with diagnosing this condition. MRI is investigation of choice.

Nodules of the metaplastic development are normally seen inside the synovium or attached to it loosely. Immunohistochemical study directed by Allard et al, which expresses that in all joints at the intersection with synovium, a vascular, wedge-shape tongue of tissue was found to cover the ligament surface ${ }^{1}$. This minor tissue overlying ligament was in coherence with and immunohistochemically like the adjacent synovial tissue. Management is mostly surgical ${ }^{6}$. Open and arthroscopic procedures can be used to treat this condition. Synovectomy gives better outcome when compared to loose body removal alone. Total knee arthroplasty is likewise a choice if synovial chondromatosis is concurrent with osteoarthritis. Complications of synovial chondromatosis can be secondary osteoarthritis, malignant transformation and recurrence. Pigmented villonodular synovitis, Synovial hemangioma, and lipoma arborescens are few conditions which mimic synovial chondromatosis $5,7,8$. Radiography and histology may help in accurately differentiate amongst them.

\section{CONCLUSIONS}

Clinical diagnosis is difficult, consistency of clinical, radiological and histological findings should be taken in to consideration in every case. Peculiarity in this case is presenting age.

\section{REFERENCES}

[1] Kukreja S. A case report of synovial chondromatosis of the knee joint arising from the marginal synovium. Journal of Orthopaedic Case Reports 2013;3(1):7-10.

[2] Milgram JW. Synovial osteochondromatosis: a histopathological study of thirty cases. J Bone Joint Surg Am 1977;59(6):792-801.

[3] Taglialavoro G, Moro S, Stecco C, et al. Bilateral synovial chondromatosis of the first metatarsophalangeal joint: a case report. Reumatismo 2003;55(4):263-6.

[4] Boya H, Pinar H, Ozcan O. Synovial osteochondromatosis of the suprapatellar bursa with an imperforate suprapatellar plica. Arthroscopy 2002;18(4):E17.

[5] Murphy FP, Dahlin DC, Sullivan CR. Articular synovial chondromatosis. J Bone Joint Surg Am 1962;44:77-86.

[6] Jeffreys TE. Synovial chondromatosis. J Bone Joint Surg Br 1967;49(3):530-4.

[7] Yu GV, Zema RL, Johnson RWS. Synovial osteochondromatosis. A case report and review of the literature. J Am Podiatr Med Assoc Journal 2002;92(4):247-54.

[8] Serbest S, Tiftikçi U. A neglected case of giant synovial chondromatosis in knee joint. Pan African Medical Journal 2015;22:5. 